\title{
Diversity, Distribution, Indigenous Uses and Conservation of Orchids in Parvati Valley of Kullu District, Himachal Pradesh, Northwestern Himalaya
}

\section{Sharma $P^{1 *}$ and Samant SS $^{2}$}

${ }^{1}$ Himachal Pradesh State Biodiversity Board, State Council for Science, Technology and Environment, Kasumpti, Shimla, Himachal Pradesh, India ${ }^{2}$ G.B. Pant National Institute of Himalayan Environment and Sustainable Development, Himachal Unit, Mohal Kullu, Himachal Pradesh, India

\begin{abstract}
The Indian Himalayan Region (IHR) is known as the repository of biodiversity. It supports 8,000 species of angiosperms. The orchidaceae is among the dominant family of angiospecies and highly evolved family among the monocotyledon. The species of this family are facing tremendous pressure due to habitat degradation, overexploitation and changing environmental conditions. Therefore, while exploring the floristic diversity of Parvati Valley, attempts have also been made to explore the orchid diversity and analyze for diversity, distribution patterns, nativity, endemism, threat categories and indigenous uses. Total 19 species of the orchids representing 13 genera were recorded between $1100-3600 \mathrm{~m}$ amsl. Of these, 13 species were natives, 6 species near endemic and 5 species non-natives. These species represented in grassland, shady moist, forests, alpine meadows, moist rocks and bouldary habitats. These species were used for curing various diseases/ailments by the inhabitants of the valley. Due to habitat degradation the populations of these species are decreasing fast. The over exploitation, habitat degradation and changing environmental conditions of these species has led rapid population depletion. Therefore, appropriate strategy has been suggested for the conservation and management of these orchids.
\end{abstract}

Keywords: Diversity; Distribution; Native; Threat categories; Indigenous uses; Orchids

\section{Introduction}

The Indian Himalayan Region (IHR) comprises of three biogeographic zones and eight bio-geographic provinces and extends from Jammu \& Kashmir in the North-West to the Arunachal Pradesh in the East [1]. Indian Himalayan Region one of the mega hot spot of biological diversity [2], is a source of a great diversity of food, fuel, fodder, timber, dye and medicinal plants. It comprises about $18 \%$ of India and is more than $2,800 \mathrm{~km}$ long and 220 to $300 \mathrm{~km}$ wide, with altitudes from 200-8000 m [3]. The vegetation comprises of tropical, sub-tropical, temperate, sub-alpine and alpine types [4].

The IHR supports about 8,000 flowering plants and family orchidaceae is one of the species rich families of angiosperms $[5,6]$. Orchids are worldwide famous for their charming and long lasting flowers. They form a unique group of plants and represent a peak in the evolution of monocots. They are terrestrial (including lithophytes, epiphytes and saprophytes) in nature. The diversity of orchids decreases from North East to North West Himalaya [6-8].

In general, a large number of studies have been carried out on the orchids of IHR [5,6,9-15]. In particular in Himachal Pradesh a very few studies are available on orchids [15-18]. However, studies at watershed/ valley level for the exploration of orchids have not been carried out, which is most important for the conservation and management of orchids. Therefore, the present attempt has been made to:

(1) Assess and identify the orchids diversity,

(2) Assess the status and distribution pattern of native and endemic orchids,

(3) Assess the economically important orchid diversity,

(4) Assess orchid diversity for threat categories, and

(5) Suggest strategy plans for the conservation of orchid diversity.

\section{Materials and Methods}

\section{Study area}

The Parvati Valley $\left(31^{\circ} 58^{\prime} 41^{\prime \prime}\right.$ to $32^{\circ} 05^{\prime} 51^{\prime \prime} \mathrm{N}$ Latitudes and $77^{\circ}$ $14^{\prime} 23^{\prime \prime} \mathrm{E}$ to $77^{\circ} 27^{\prime} 08^{\prime \prime}$ E Longitudes), ranging from $1,100-4,800 \mathrm{~m}$, is remarkably beautiful and just a little sinister (Figure 1). The valley is very narrow with the mountains rising steeply on both sides, allowing a couple less hours of light than in erstwhile areas. The Parvati River is a main drainage of the watershed and supported by its tributaries such as Malana nallah, Tosh nallah, Grahan nallah, etc. The unique topography, diverse habitats and climatic conditions support rich biodiversity. The village Malana nestled between Jari and Khiksa thatches is the oldest democracy in the world. The area receives heavy snowfall during winter and rainfall in rainy season. The soil comprises laterite, red, sandy, loamy and alluvial types and composition of the soil depends upon the underlying rocks and effect of various agencies from time to time. The vegetation mainly comprises of sub-tropical, temperate, sub-alpine and alpine types. The inhabitants are largely dependent on biodiversity for their sustenance. Due to over exploitation and habitat degradation the economically important biodiversity is under tremendous pressure.

\section{Surveys, sampling, identification and data analysis}

The extensive field surveys were conducted to explore the orchid diversity of the Parvati Valley between 1,100-3,600 m during 2009-

*Corresponding author: Pankaj Sharma, Sr. Scientific Professional, Himachal Pradesh State Biodiversity Board, State Council for Science, Technology and Environment, B-34, SDA Complex, Kasumpti, Shimla-171009, Himachal Pradesh, India, Tel: +91- 94187-76534; Fax: 0177-2620998; E-mail: spankaj80@gmail.com

Received October 17, 2016; Accepted January 09, 2017; Published January 16 2017

Citation: Sharma P, Samant SS (2017) Diversity, Distribution, Indigenous Uses and Conservation of Orchids in Parvati Valley of Kullu District, Himachal Pradesh Northwestern Himalaya. J Biodivers Endanger Species 5: 177. doi: 10.4172/2332 2543.1000177

Copyright: ( 2017 Sharma P, et al. This is an open-access article distributed under the terms of the Creative Commons Attribution License, which permits unrestricted use, distribution, and reproduction in any medium, provided the original author and source are credited. 


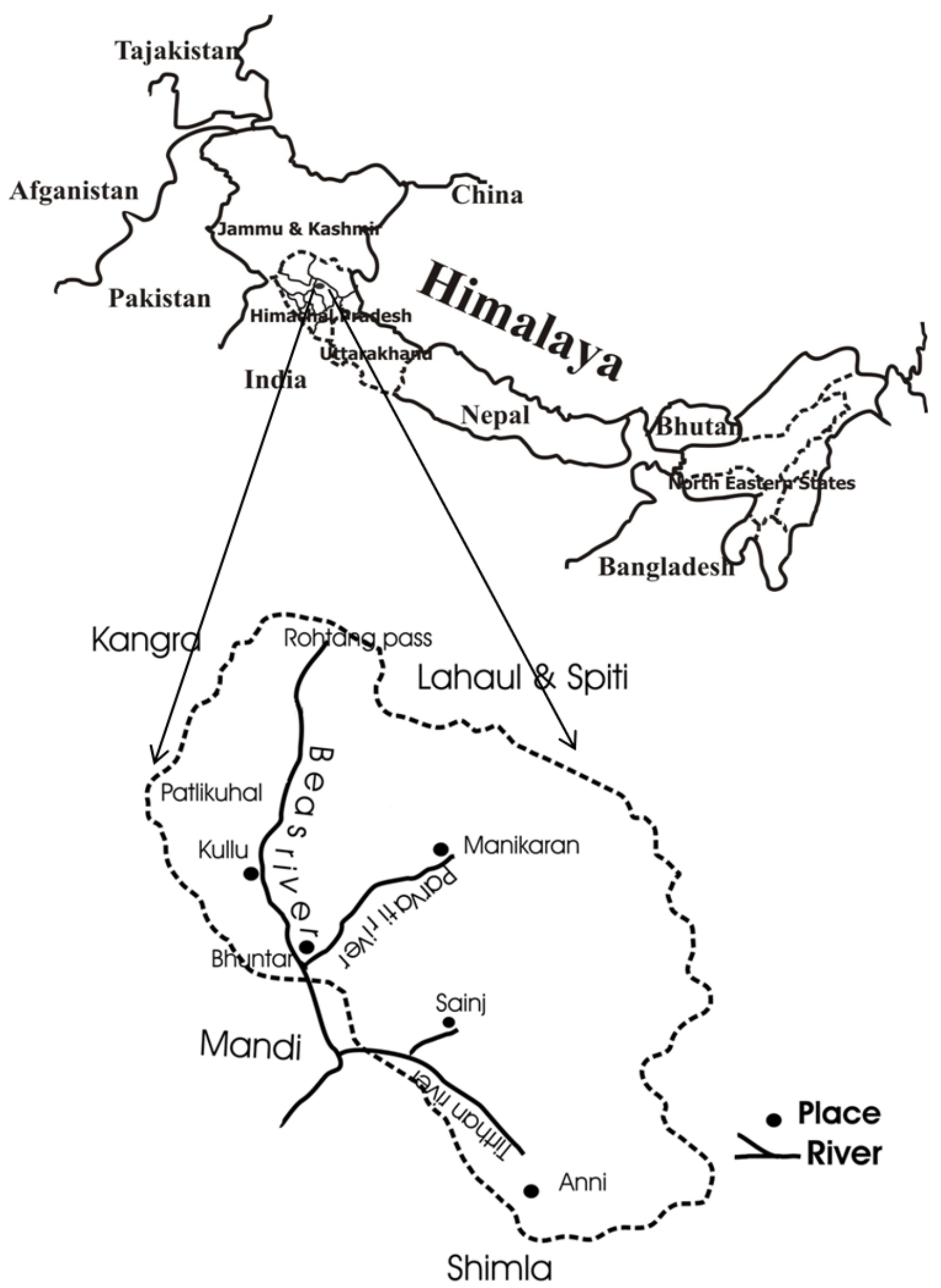

Figure 1: Location map of study area. 
Citation: Sharma P, Samant SS (2017) Diversity, Distribution, Indigenous Uses and Conservation of Orchids in Parvati Valley of Kullu District, Himachal Pradesh, Northwestern Himalaya. J Biodivers Endanger Species 5: 177. doi: 10.4172/2332-2543.1000177

2013. The rapid sampling of species was done and the samples of each species were collected for proper identification. For each species, information on habit, habitat, altitudinal range, population size, indigenous uses, etc. was collected. The species were identified with the help of flora $[8,14,19,20]$. Species were analyzed for nativity, endemism and rarity. Nativity of the species was identified [4,5,21]. Endemism of the species was identified based on distribution range [4,22]. Species confined to the IHR were considered as endemic, and those with a distribution extending to neighboring countries i.e., Himalayan region of Afghanistan, Pakistan, Tibet, Nepal, Bhutan and adjacent states of the IHR were considered as near endemics. Threat categories were identified [23]. Information on the indigenous uses of the species is based on the available literature and interviews of the inhabitants $[5,24]$.

\section{Results}

\section{Diversity and distribution}

A total of 19 species of the orchids representing 13 genera were recorded between $1100-3600 \mathrm{~m}$ amsl. Of these, 7 species of orchids were recorded from $<1800 \mathrm{~m}$ altitudinal zone, followed by the 1801 $2800 \mathrm{~m}$ zone (15 spp.) and $>2800 \mathrm{~m}$ (16 spp.), respectively (Figure 2). The diversity of orchid increases with the increase in altitude and vice-versa. These species were found in grasslands, shady moist places, forests, alpine meadows, moist rocks and boulders.

\section{Nativity and endemism}

Thirteen species (i.e., Calanthe tricarinata, Dactylorhiza hatagirea, Epipactis helleborine, Galeola lindleyana, Goodyera biflora, G. fusca, Gymnadenia orchidis, Habenaria edgeworthii, H. elisabethae, Herminium lanceum, $H$. monophyllum, Neottia listeroides and Satyrium nepalense) were natives, 6 species (i.e., Calanthe tricarinata, Epipactis helleborine, Galeola lindleyana, Goodyera biflora, Habenaria edgeworthii and Herminium lanceum) near endemic and 5 species (i.e., Cephalanthera longifolia, Epipactis gigantea, Herminium monorchis, Malaxis muscifera and Spiranthes sinensis) non-natives (Appendix).

\section{Threat categorization}

Of the total species, 3 spp. have been identified as Critically Endangered, 1 species as endangered, 2 species as vulnerable and 9 species as near-threatened. According to the International Union for Conservation of Nature (IUCN), 2 species have been categorized as Critically Endangered globally, 4 species as rare and 1 species nearthreatened (Figures 3-5; Appendix) [23].

\section{Indigenous Uses}

Leaves (6 spp.), bulb (2 spp.), stems (1 sp.), tubers (12 spp.) and aerial parts ( $3 \mathrm{spp}$.) were used by the inhabitants for their therapeutic use (Figure 3). These species are used for curing various ailments such as sores, eczema, paralysis, healing wounds, bone fracture, cough, cold, cuts, sexual disability, rheumatism, fever, blood purification, cold, kidney disorder, female disorder, dysentery, sterility, leucorrhea, diabetes, malaria, etc., and also used as aphrodisiac, antispasmodic, sedative, febrifuge, appetizer and tonic (Appendix). Due to habitat degradation the populations of these species are decreasing fast. Dactylorhiza hatagirea and Malaxis muscifera are commercially exploited by the inhabitants.

\section{Discussion and Conclusion}

The state Himachal Pradesh forms the parts of Trans and North Western Himalaya, supports relatively very less number of orchids compared to Western, Central and Eastern Himalaya [5,8]. Mostly terrestrial orchids are found in the state except Gastrochilus calceolaris, Aerides multiflora and Rhynchostylis retusa, which are epiphytic in nature $[8,18]$.

The occurrence of representative, natural, unique and socioeconomically important orchids in the area indicates high conservation and socio-economic values and merit priority attention for conservation of these species [5]. In Parvati Valley, the inhabitants are largely dependent on forests for grazing, fuel, fodder, timber, medicinal and wild edible plants, making agricultural tools, etc. Due to continuous use of economically important species, their populations are depleting rapidly and habitat degradation has increased many folds [24]. Besides these, orchids are extensively used in the traditional systems of medicines [18]. Dactylorhiza hatagirea and Malaxis muscifera are commercially exploited in the area. Due to high commercial values of Dactylorhiza hatagirea and Malaxis muscifera as medicine and food, these species are facing tremendous pressure and these species have been identified as Critically Endangered, globally [23-26]. If over exploitation and habitat degradation continues, these species may become extinct from the area. The other species are also exploited for curing various diseases and other purposes. Therefore, study on habitat ecology, mass multiplication using convention and in-vitro, propagation methods, establishment and maintenance in ex-situ and in-situ conditions, promotion of orchids, educational and awareness programmes on status, conservation and management of the orchids, promotion of orchid species with high aesthetic value in floriculture; and involvement of inhabitants in the conservation management have been suggested. So that the gene pool of this unique group of plants could be maintained posterity.

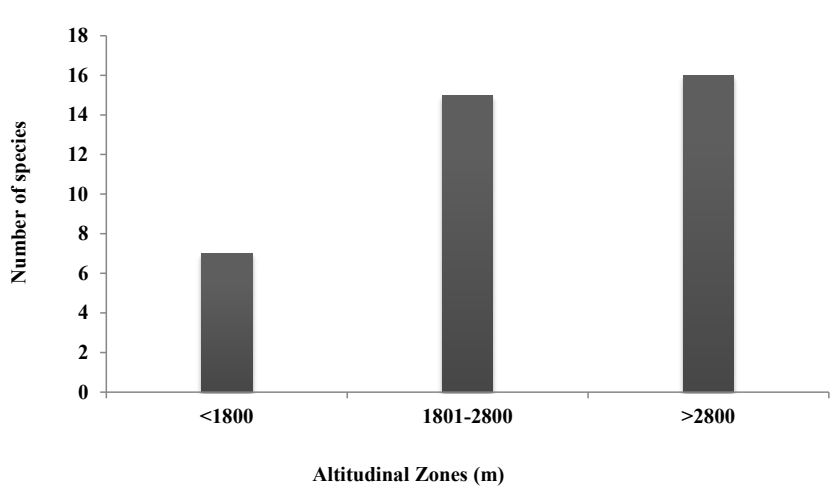

Figure 2: Altitudinal distribution of orchids in Parvati Valley.

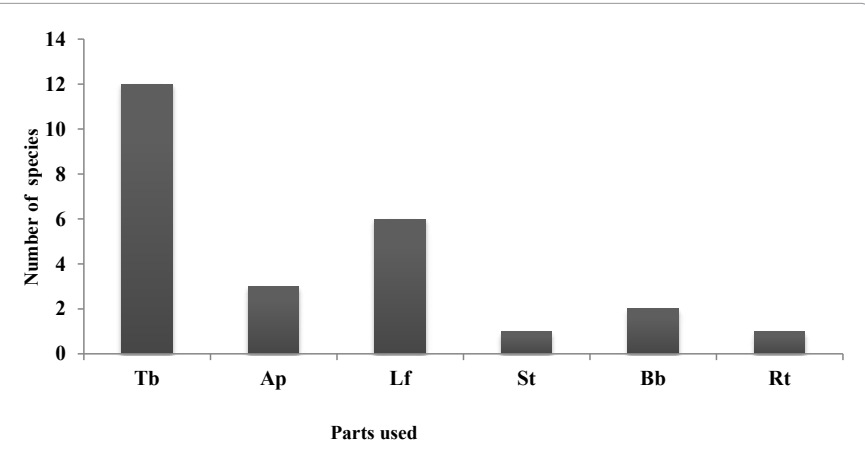

Figure 3: Various parts of economically important orchids used by the inhabitants of Parvati Valley. Lf: Leaf; Bb: Bulb; Rt: Root; St: Stem; Tb: Tuber; Ap: Aerial Parts; Rt: Root. 
Citation: Sharma P, Samant SS (2017) Diversity, Distribution, Indigenous Uses and Conservation of Orchids in Parvati Valley of Kullu District, Himachal Pradesh, Northwestern Himalaya. J Biodivers Endanger Species 5: 177. doi: 10.4172/2332-2543.1000177

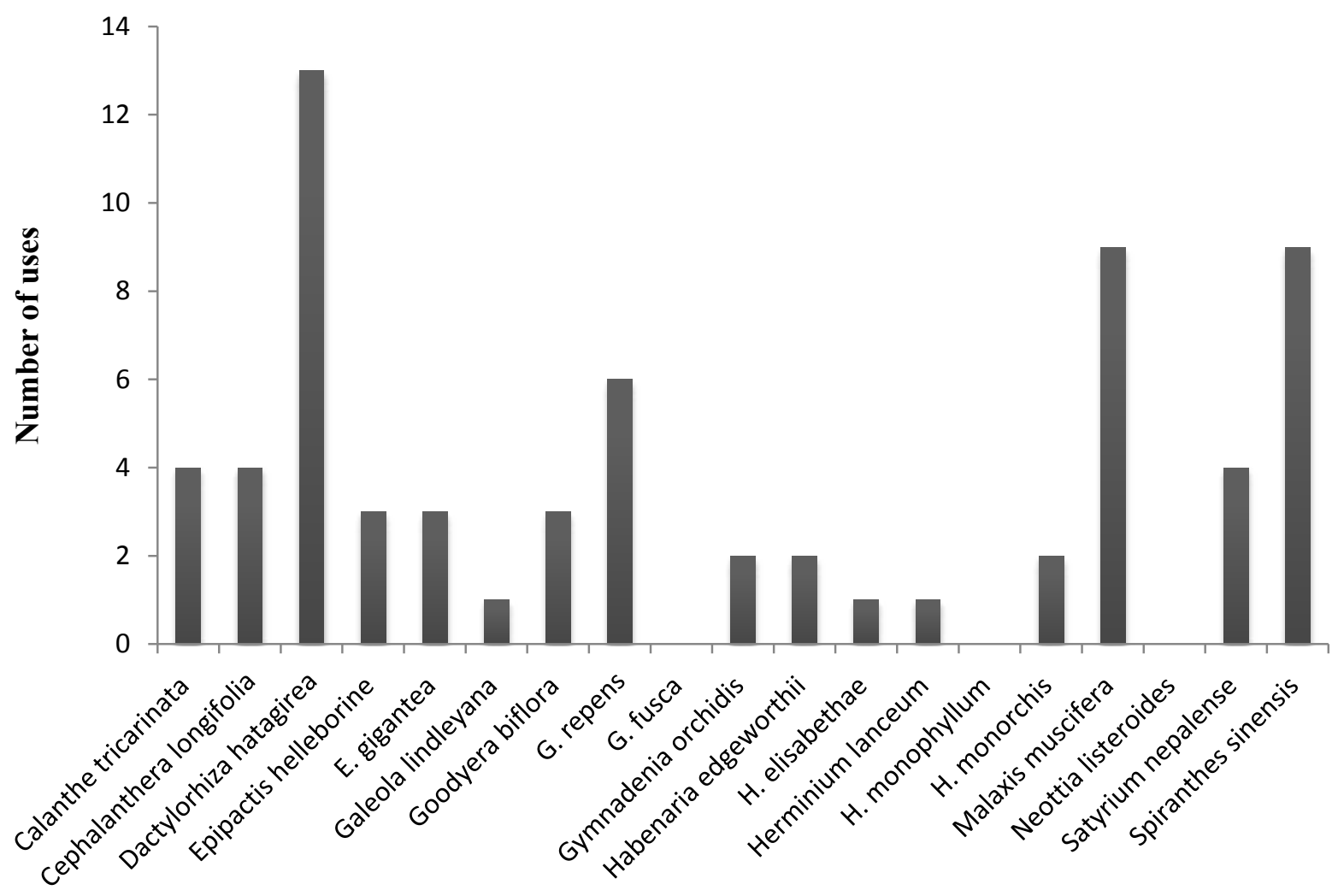

Species

Figure 4: Uses of orchids in Parvati Valley.

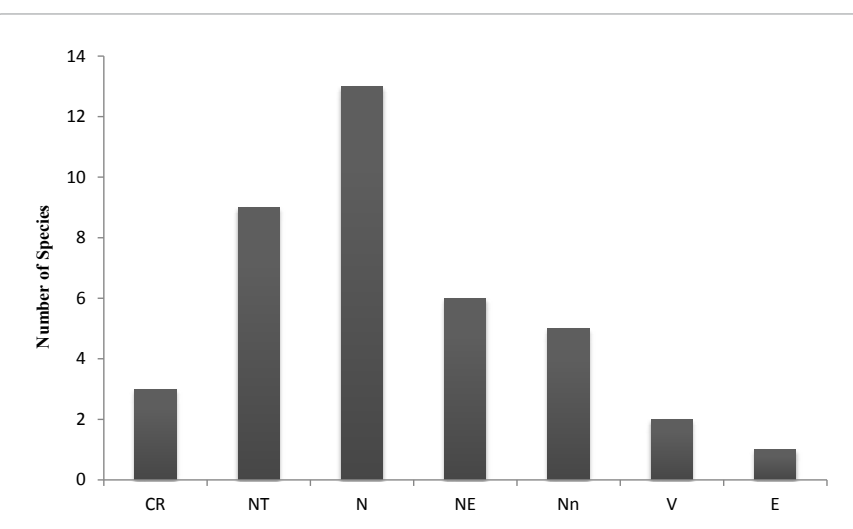

Figure 5: Threatened, native and near endemic orchids of Parvati Valley. CR: Critically Endangered; NT: Near-Threatened; N: Native; NE: Near-Endemic; Nn: Non-Native; V: Vulnerable; E: Endangered.

\section{Acknowledgement}

The authors are thankful to the Director, G.B. Pant National Institute of Himalayan Environment \& Sustainable Development (GBPINIHESD), KosiKatarmal, Almora for facilities and encouragement. The inhabitants of the area are acknowledged for providing valuable information during the field surveys.

\section{References}

1. Rodger WA, Panwar WS (1988) Planning wildlife protected area network in India. Wildlife Institute of India, Dehradun.

2. Myers N, Mittermeier RA, Mittermeier CG, da Fonseca GA, Kent J (2000) Biodiversity hotspots for conservation priorities. Nature 403: 853-858.
3. Anonymous (1992) Action Plan for Himalaya. G B Pant Institute of Himalayan Environment \& Development, Kosi-Katarmal, Almora.

4. Sharma P (2013) Ecological assessment of floristic diversity and possible impacts of hydropower projects in Kullu District of Himachal Pradesh, North Western Himalaya. Thesis submitted to Kumaun University Nainital, p: 411.

5. Samant SS (2002) Diversity, distribution and conservation of orchids of TransNorthwest, and West Himalaya. J Orchid Soc India 16: 65-74.

6. Singh DK, Hajra PK (1996) Floristic diversity. In: Gujral GS and Sharma V (eds.) Changing perspectives of Biodiversity Status in the Himalaya. British Council, New Delhi, pp: 23-38.

7. Chowdhery HJ, Wadhwa BM (1984) Flora of Himachal Pradesh. Botanical Survey of India, Howrah, p: 860.

8. Deva S, Naithani HB (1986) The Orchid Flora of North West Himalaya. Print and Media Associates New Delhi, India, p: 451.

9. Arora CM (1986) Status of orchids species in North-Western Himalaya and their conservation with special reference to Orchid belt in Kumaun Hills. In: Biology, Conservation, and Culture of Orchids, pp: 397-400.

10. Balodi B (1987) The Flora of Gori Valley (Kumaun). D.Phil. Thesis, Garhwal University, Srinagar (Garhwal).

11. Duthie JF (1906) The Orchids of North-Western Himalaya. Ann Roy Bot Gard 9: 81-211.

12. Jalal JS, Kumar P, Rawat GS, Pangtey YPS (2008) Orchidaceae, Uttarakhand, Western Himalaya, India. Check List 4: 304-320.

13. Pangtey YPS, Samant SS (1987) Some orchids new to the flora of Nainital. J Econ Tax Bot 11: 1-4.

14. Pangtey YPS, Samant SS, Rawat GS (1991) Orchids of Kumaun Himalaya Bishen Singh Mahendra Pal Singh, Dehradun, India, p: 193. 
Citation: Sharma P, Samant SS (2017) Diversity, Distribution, Indigenous Uses and Conservation of Orchids in Parvati Valley of Kullu District, Himachal Pradesh, Northwestern Himalaya. J Biodivers Endanger Species 5: 177. doi: 10.4172/2332-2543.1000177

Page 5 of 5

15. Vij SP, Navdeep Shekhar SK, Garg AK (1983) Observations on the orchids of Nainital and adjacent hills in the Central Himalaya (Ecology and distribution). Res Bull Sci Panjab Univ 34: 63-76.

16. Chauhan NS (1990) Medicinal orchids of Himachal Pradesh. J Orchid Soc India 4: $99-105$.

17. Lal B, Negi HR, Singh RD, Ahuja PS (2004) Medicinal Uses of Dactylorhiza hatagirea among the natives of higher altitudes in Western Himalaya. J Orchid Soc India 18: 97-100.

18. Rana MS, Lal M, Sharma A, Samant SS (2008) Ecological evaluation of orchid diversity in Kullu district, Himachal Pradesh, India. J Orchid Soc India 22: 7784.

19. Dhaliwal DS, Sharma M (1999) Flora of Kullu District (Himachal Pradesh). Bishen Singh Mahendra Pal Singh, Dehradun, p: 744.

20. Singh SK, Rawat GS (2000) Flora of Great Himalayan National Park, Himachal Pradesh. Bishen Singh Mahendra Pal Singh, Dehradun, p: 304.
21. Anonymous (1883-1970) Index Kewensis Plantarum Phanerogamarum Vol 1-2 (1883-1885) and 15 Suppl. (1886-1970). Clarendron Press, Oxford.

22. Dhar U, Samant SS (1993) Endemic diversity of Indian Himalaya. I Ranunculaceae and II. Paeoniaceae. J Biogeography 20: 659-668.

23. Ved DK, Kinhal GA, Ravikumar K, Prabhakaran V, Ghate U, et al. (2003) Conservation assessment and management prioritization for the medicinal plants of Jammu and Kashmir, Himachal Pradesh and Uttaranchal. Foundation for Revitalisation of Local Health Traditions, Bangalore, India, p: 206.

24. Samant SS, Pant S, Singh M, Lal M, Singh A et al. (2007) Medicinal Plants in Himachal Pradesh, North Western Himalaya, India. Int J Biod Sci Mangt 3: 234-251.

25. Aswal BS, Mehrotra BN (1994) Flora of Lahaul-Spiti (A Cold Desert in NorthWest Himalaya). Bishen Singh Mahendra Pal Singh, Dehradun.

26. Collett H (1902) Flora Simlensis. Thacker Spink. \& Co. Calcutta and Shimla Reprinted 1971. Bishen Singh Mahendra Pal Singh, Dehradun, p: 652. 